\title{
Analysis of the Relationship between Inflation, Unemployment and Economic Growth in Nigeria: 1987-2012
}

\author{
Mohammed Yelwa ${ }^{1}$, Okoroafor O.K.David ${ }^{1} \&$ Awe, Emmanuel Omoniyi ${ }^{1}$ \\ ${ }^{1}$ Department of Economics University of Abuja-Gwagwalada, Nigeria. \\ Correspondence: Mohammed Yelwa, Department of Economics University of Abuja-Gwagwalada, Nigeria.
}

Received: March 20, 2015

Accepted: April 10, 2015

Available online: July 10, 2015

doi:10.11114/aef.v2i3.943

URL: http://dx.doi.org/10.11114/aef.v2i3.943

\begin{abstract}
This paper provides analysis of the relationship between unemployment, inflation and economic growth in Nigeria: 1987-2012. The study utilizes secondary data to analyze the relationship between unemployment, inflation and economic growth. The methodology used for the study was ordinary least squares. The results confirms that in the long run, interest rate and total public expenditure have significant impact on economic growth in Nigeria, while inflation and unemployment has inverse effects on growth in Nigeria. The possible justification for the inverse effect of inflation on price level is that inflation may not be due to aggregate demand pressure but rather due to hiccups in the supply chain of goods both from the domestic and foreign supply outlets. Empirical deductions also signify the presence of significant feedback from the long run to short run disequilibrium. However, there exists a causal linkage between inflation, unemployment and economic growth in Nigeria. In conclusion, the paper recommended that the government must as a matter of necessity to improve or continue to fine-tune macroeconomic policy instruments to achieve a sustainable and enable environment that will enhance increase in domestic output.
\end{abstract}

Keywords: unemployment, inflation and economic growth.

\section{Introduction}

Inflation and unemployment has seen to be a serious determinants of underdevelopment in any nation including Nigeria. The Nigerian economy has not been impressive despite the huge human and natural resources. Nigerian economy is characterized with low per capita income, high level of inflation and unemployment and many socio-economic challenges. The economy has continued to witness economic recovery which is immediately followed by economic recession and depression. Adebayo and Ogunrinola,(2006).

Unemployment is not only seen as a colossal waste of a country's manpower resources, it generates welfare loss in terms of lower output thereby leading to lower income and well-being of the citizens (Raheem, 1993). Unemployment is a very serious issue in Africa (Oladeji, 1994 and Umo, 1996). The need to avert the negative effects of unemployment has made the tackling of unemployment problems to feature very prominently in the development objectives of many developing nations.

Economic performance has not been highly impressive. The continued economic crisis, with the associated problems of high inflationary pressure, high exchange rate, debt overhang, adverse balance of payment and high inflation rates have been on the increase. Against a high rate of unemployment and underemployment, a large public sector, low wages and poor working conditions have been premised on high inflation rate in Nigeria. Also, underemployment and unemployment is prominent feature of the informal labour market as well. Consequently, the full potentials of labour-surplus economy have not been fully exploited. Adebayo, (2010).

In the 1960s and 1970s, the Nigerian economy provided jobs for almost all job seekers and absorbed considerable imported labour while inflation rates were low. The wage rate compared favorably with international standards and there was relative industrial peace in most of the years. Following the oil boom of the 1970s, there was mass migration of people, especially the youth, to the urban areas seeking for white- collar jobs.

Following the downturn in the economy in the early 1980s, the problems of unemployment and inflation increased, which brought the introduction of the Structural Adjustment Programme (SAP). The rapid depreciation of the naira exchange rate since 1986 and the inability of most industries to import the raw materials required to sustain their output 
levels have led to inflation. A major consequence of the rapid depreciation of the naira was the sharp rise in the general price level, leading to a significant decline in real wages and increased poverty. The low wages in turn contributed to a weakening of the purchasing power of wage earners and declining aggregate demand. Consequently, industries started to accumulate unintended inventories. Raheem, (1993).

Unemployment and inflation are two intricately linked economic concepts. Over the years there have been a number of economists and policy-makers trying to interpret the relationship between the concepts of inflation and unemployment.

The relationship between unemployment and inflation is commonly described as the Phillips curve. In the short term the Phillips curve happens to be a declining curve. The Phillips curve in the long term is distinct from the Phillips curve in the short term. It has been observed by the economists that in the long run the concepts of unemployment and inflation are not related.

Unemployment has been categorized as one of the serious impediments to social welfare. Apart from representing a colossal waste of a country's manpower resources, it generates welfare loss in terms of lower output, thereby leading to lower income and wellbeing. The need to avert the negative effects of unemployment has made the tackling of unemployment problem to feature very prominently in the development objectives of many developing countries. One of the steps taken by the Nigerian government to reduce the problem of youth unemployment in Nigeria was the establishment of National Directorate of Employment (NDE). Even though, the agency has been performing below expectations .Against this background, the paper seeks to examine the impact of Unemployment and inflation on economic growth in Nigeria.

The paper has contributed to the body of existing literature and filled some gaps that were not discuss, and is significance to economic decision-makers, as it will assist us with the basic knowledge and skills needed to tackle the pressing issue of unemployment and inflation in Nigeria.

However, a good deal of research work has been carried out on unemployment and inflation worldwide, but not much has been carried out using the Nigerian economy and within the scope of our analysis.

\section{Literature Review}

\subsection{The Concept of Inflation and Unemployment}

The concept of inflation has been define as a persistence rise in the general price level of broad spectrum of goods and services in a country over a long period of time. Inflation has been intrinsically linked to money, as captured by the often heard maxim ,„,inflation is too much money chasing too few goods ${ }^{\text {eeee }}$. Hamilton (2001) inflation has been widely described as an economic situation when the increase in money supply is ,„,fastereec than the new production of goods and services in the same economy. Piana (2001) economists usually try to distinguish inflation from an economic phenomenon of a onetime increase in prices or when there are price increases in a narrow group of economic goods or services.

Balami (2006) also sees inflation as a situation of a rising general price level of broad spectrum of goods and services over a long period of time. It is measured as the rate of increase in the general price level over a specific period of time.

The International Labour Organization (ILO) defines the unemployed as numbers of the economically active population who are without work but available for and seeking work, including people who have lost their jobs and those who have voluntarily left work (World Bank, 1998). Although there seems to be convergence on this concept, its applications have been bedeviled with series of problems across countries. First, most published unemployment rates are recorded open unemployment. People's attitude on this varies from country to country. While this may be high in developed countries and where government is committed to resolving unemployment problems, it is likely to be very low in countries with the opposite attributes.

Okafor (2011) also pointed out the problem arising from the concept of labour force. In most countries, particularly Nigeria, people below the age of 15 years and those above the age of 55, who are actively engaged in economic activities, is usually excluded from labour statistical surveys. All these factors have the tendency to result in underestimation of unemployment thereby making international comparison very difficult. Factors such as the preponderance of full housewives (but who are willing to be engaged in paid job) and unpaid family workers also contribute significantly to the underestimation of unemployment.

Frictional unemployment may be regarded as subset of structural unemployment, mainly reflecting temporary unemployment spells as a result of job search and matching difficulties in connection with quits, new entries to the labour market, and job separation because of employers' dissatisfaction with the individual workers (Lindbeck, 1999). Ordinarily, this kind of unemployment does not usually pose much threat to individual's welfare, as it is temporary in nature. However, the situation in Nigeria is that of frictional unemployment growing into a long - term unemployment and thereby resulting into a stable state of unemployment (Tairu, 2003). This is often described as equilibrium 
unemployment.

In recent times, the definition of unemployment by the International Labour Organization (ILO) is said to be more encompassing, "the unemployed is a member of the economically active population, who are without work but available for and seeking for work, including people who have lost their jobs and those who have voluntarily left work (World Bank, 1998). The application of this definition across countries has been faulted, especially for the purpose of comparison and policy formulation, as countries characteristics are not the same in their commitment to resolving unemployment problems, moreso, the preponderance of housewives who posses the ability and willingness to work, the definition of the age bracket all stand as limitations to the definition by ILO (Douglason et al, 2006).

According to the Central Bank of Nigeria (2003) the national unemployment rate, rose from 2.3 percent in 1970 to 6.4 percent in 1980. The high rate of unemployment observed in 1980 was attributed largely to depression in the Nigerian economy during the late 1970s. Specifically, the economic downturn led to the implementation of stabilization measures which included restriction on exports, which caused import dependency of most Nigerian manufacturing enterprises, which in turn resulted in Operation of many companies below their installed capacity. This development led to the close down of many industries while the survived few were forced to retrench a large proportion of their workforce, furthermore, the Nigerian Government also placed an embargo on employment. Specifically total disengagement from the Federal Civil Service rose from 2, 724 in 1980 to 6,294 in 1984 (Odusola, 2001).

Owing to this, the national unemployment rate fluctuated around $6.0 \%$ until 1987 when it rose to 7.1 percent. It is important to state here, that SAP adopted in 1986, had serious implications on employment in Nigeria, as unemployment rate declined from 7.1 percent in 1987, to as low as 1.8 percent in 1995 , after which it rose to 3.4 percent in 1996, and hovered between 3.4 and 4.7 percent between 1996 and 2000 (Douglason et al, 2006).

The analysis by educational status also suggests that people who have been majorly affected by unemployment are those without basic education. For instance, persons with and without primary school education accounted for 76.8/80.6 percent of the unemployment in 1974 and 1978 respectively. In recent times however, the situation has been compounded by the increasing unemployment of professionals such as accountants, engineers, among others. According to a 1974 survey, reported by Aigbokhan (2002) graduate unemployment accounted for less than 1 percent of the unemployed, in 1974, by 1984, the proportion rose to 4 percent for urban areas and 2.2 percent in the rural areas. Graduate unemployment, (Dabalen et al, 2000) accounted about 32\% of the unemployed labour force between 1992 and 1997.

It is impressive to note that, in 2003, Nigerian's unemployment rate declined substantially to 2.3 percent. This decline was attributed to the various government efforts aimed at addressing the problem through poverty alleviation programmes. This decline also pointed to an increased number of people who got engaged in the informal sector activities.

A couple of recent studies have attempted to examine the contributions of Informal Sector to employment creation. Ajibefun and Daramola (2003) examined the efficiency of micro enterprises in the Nigerian economy using a sample of 180 micro enterprises. They reported evidence of a wide variation in technical and allocative efficiencies, both within and across industries. They also found that education of owner of a business enterprise was a significant factor influencing efficiency. They conclude that the evidence of variations in efficiency is indicative of the need for more proactive actions to raise the level of efficiency and employment among the firms in the sample. The international labour organisation noted that

Global youth unemployment has reached its highest level on record, and is expected to increase through 2010.The organization noted that the crisis added to the ranks of vulnerable employment and informal sector employment in developing economies. In a related development the world economic crisis stimulated high unemployment rate, which it described as unprecedented. ILO, (1998)

Abachi, (1998) Studied the trade-off between unemployment and inflation in Nigeria, using a trade-off model used by Rea (1983). His studies revealed that there is no trade-off between inflation and unemployment. Rather, the estimates established a non-linear curve that slopes upwards. Also, his findings showed that causality existed between inflation and unemployment, which implies that any attempt to control inflation results to the aggravation of unemployment and vice-versa.

Sanda et al.(2006) used a sample of 360 firms in Kano and its environs to examine whether or not, in comparison to large firms, small firms are relatively better at creation of employment opportunities. Their results were positive in that small firms were found to be relatively better, and the conclusion they derived was that a policy that gives special preference to small firms is justified. 


\subsection{Unemployment and Economic Growth}

The adverse effect of high unemployment on the domestic economy cannot be quantified. The availability of abundant human resources if utilized could serve as great catalyst to economic growth but if otherwise, could exert negative influence on the economy. The unutilized large quantum of human resources in Nigeria due to non - availability of employment opportunities has continued to impede on the prospect of growth in several ways. The resulting effect of unemployment such as perpetration of violence and general insecurity threatens economic growth and development to a large extent. Therefore, rather than being a source of growth stimulation, the army of the unemployed remains a potential threat to the well - being of the economy. It's imperative to note that at a social level, prolonged unemployment usually results in some form of social pathology, as reflected by an increased crime rate and violent agitators. It breeds discontent against the state, and any slight provocative issue or incident may trigger violent demonstrations and social unrest, which may result in loss of life and damage to property, if the situation is not handled properly by the authorities.

\subsection{Nexus between Unemployment and Inflation}

Even though unemployment is painful to those who have no source of income, reducing unemployment is not costless. In the short-run, a reduction in unemployment may come at the expense of a higher rate of inflation, especially if the economy is close to full capacity, where resources are almost fully employed.

There are two possible explanations of this relationship- one in the short-run and another in the long-run. In the short-run, there is an inverse relationship between the unemployment and inflation (Phillips curve), while it has been observed by economists that in the long-run the concepts of unemployment and inflation are not related. The relationship has presented regulators with a number of problems.

\section{Theoretical Framework and Methodology}

An endogenous model of economic growth appears to be the most suitable theoretical framework for this study. The model suggests that endogenous factors such as government policies, political stability, market distortions, human capital etc., can significantly affect economic growth. It is a widely used growth model to provide a systematic investigation of the government policies and programmes.

The framework of this study is adapted from Adamu (2003). It assumes a standard neoclassical production function which is premise on changes in quantities of factors of production account for growth. The neo-classical model is based on the Cobb-Douglas production function and is given as:

$$
Y=f\left(A_{t}, K_{t}, L_{t}\right)
$$

The neoclassical growth theory states that the changes in quantities of factor inputs in production (capital and labour) account for growth of output (Solow 1957).

Where:

$$
\begin{gathered}
\mathrm{Y}=\text { Aggregate real output } \\
\mathrm{K}=\text { Capital } \\
\mathrm{L}=\text { Labour force } \\
\mathrm{A}=\text { Level of technology } \\
\mathrm{T}=\text { time dimension. }
\end{gathered}
$$

\subsection{Methodology and Sources of Data Collection}

The sources of data used to this study is secondary sources and were

Sourced principally from the Central Bank of Nigeria (CBN) annual reports, statistical bulletin various issues. And in analyzing the data Ordinary least squares (OLS) were used in which RGDP was regressed against unemployment rate, interest rate, government expenditure and inflation rate. The method is useful in developing quantitative relationship between variables, which can be used for prediction. This is the most appropriate technique in view of the test for fitness and simplicity in understanding.

To estimate the parameters in the model, we assumed that the assumptions of the OLS hold. This analysis helps us to determine the extent to which the exogenous or policy variables explain the endogenous variable. The test of the explanatory parameters was carried out using the student $\mathrm{T}$ - test which determines the strength of the relationship between the independent variables in the model. It ascertains if each estimated parameters is individually significantly different from zero.

The co-efficient of determination (R2) was computed. R2 is used to measure the goodness of fit. It is used to reinforce F 
— statistic. It takes into account, the degree of freedom and tests the significance of the explained variation in the regressant by the regressor.

The Durbin - Watson (DW) value was also computed and used to determine the presence or absence of auto-correlation in the data collected.

\subsection{Model Specification}

Based on the theoretical framework, the Gross Domestic Product (GDP) growth model for Nigeria could be represented mathematically as:

RGDP $=\mathrm{f}(\mathrm{UNEMP}$, INTR, GOVTEXP, INFR $)$

Where:

$$
\begin{gathered}
\text { RGDP = Real Gross Domestic Product } \\
\text { UNEMP = Unemployment Rate } \\
\text { INTR = Interest Rate } \\
\text { GOVTEXP = Government Expenditure } \\
\text { INFR = Inflation Rate }
\end{gathered}
$$

The linear relationship of equation (1) could be stated as:

$$
\text { RGDP }=a_{0}+a_{1} \text { UNEMP }+a_{2} \text { INTR }+a_{3} \text { GOVTEXP }+a_{4} \text { INFR }+U_{t}
$$

Where $\mathrm{a}_{1}, \mathrm{a}_{2}, \mathrm{a}_{3}$ and $\mathrm{a}_{4}$ are the relevant elasticity,

$a_{0}$ is the regression constant and $U_{t}$ is the error term subject to the usual stochastic consumptions.

\section{Analysis of Results}

\subsection{Presentation of Results}

The multiple regressions is to be estimated, where the coefficients $b_{1}, b_{2}, b_{3}$, to be estimated, are used to measure the contribution of independent variables, Unemployment rate, interest rate, government expenditure and inflation rate to dependent variable rate of Real Gross Domestic Product.

The model is:

$$
\text { RGDP }=a_{0}+a_{1} \text { UNEMP }+a_{2} \text { INTR }+a_{3} \text { GOVTEXP }+a_{4} \text { INFR }+e
$$

A simple linear ordinary least squares method of estimation was applied to our earlier outlined methods. The overall results are expressed below.

$$
\begin{gathered}
\text { RGDP }=175912.4-2703.73 \text { UNEMP }+4202.62 \text { INTR }+155.66 \text { GOVTEXP }-425.9 \text { INFR } \\
\mathrm{t}=(2.278225) \quad(-0.672677)(1.152681) \quad(8.408569) \\
R^{2}=0.921 \\
\text { Adjusted } R^{2}=0.904 \\
F-\text { statistic }=55.13969 \\
D-W=2.393290
\end{gathered}
$$

Table 4.1 Results of the Stationarity (Unit Root) Test

\begin{tabular}{llll}
\hline Variables & ADF-statistic & Critical values & Order of integration \\
\hline RGDP & -3.271402 & $1 \%=-3.769597$ & Stationary at $1^{\text {st }}$ diff. \\
& $(-0.386203)$ & $5 \%=-3.004861$ & \\
UNEMP & -5.475483 & $10 \%=-2.642242$ & Stationary at $1^{\text {st }}$ diff.1 \\
& $(0.624352)$ & $5 \%=-2.998064$ & \\
INTR & & $10 \%=-2.638752$ & Stationary at level \\
& -3.840358 & $1 \%=-3.752946$ & Stationary at level. \\
GOVTEXP & & $5 \%=-2.998064$ & \\
& & $10 \%=-2.638752$ & \\
INFR & & $5 \%=-3.020686$ & Stationary at $1^{\text {st }}$ diff. \\
\end{tabular}




\subsection{Discussion of Results}

The result shows that the unemployment rate in Nigeria shows a negative and insignificant relationship with the real gross domestic product.

Also, interest rate and government expenditure show positive and significant relationship with the RGDP.

However, inflation rate corresponds to the a priori expectation of a negative relationship.

\subsubsection{Test of Goodness of Fit $\left(\mathrm{R}^{2}\right)$}

Measure the goodness of fit of our regression line, it also measure the explained and unexplained variation. It shows the percentage of the total variation in the dependent variable that can be explained by the independent variables.

The result shows the value of our Adjusted $\mathrm{R}^{2}$ as 0.90 . This implies that all the independent variables (unemployment rate, Interest rate, Government Expenditure and inflation rate) account for about $90 \%$ of the variation in Nigeria's Real Gross Domestic Product (RGDP), while the remaining 10\% is explained by other variables which was not captured by the model are included in the disturbance variable.

\subsubsection{Durbin-Watson Test}

Durbin Watson statistic measures the auto correlation. As a rule of thumb, if Durbin Watson test is 2 means the test is significant, if $\mathrm{d}<2$ means it suffer from positive serial correlation, if $\mathrm{d}>2$ means it suffer from negative serial correlation.

Since our Durbin - Watson is 2.393290 , which is approximately to two means that the regression result is free from autocorrelation problem.

\subsubsection{Unit Root Test}

The results revealed that all the variables of the model are found to be stationary at both 1 percent, 5percent, and 10 percent level with first difference (d(1)), which is indicated by ADF results at all levels less than the critical values in negative direction.

\section{Conclusion and Recommendations}

Unemployment and inflation poses a serious problem in any economy. Studies carried out by most economists revealed that in the quest to reduce unemployment, rising inflation may be risked.

We can say conclusively and without much ado that inflation and unemployment have significant impact on economic growth in Nigeria.

The trade-off relationship between unemployment and in inflation poses a dilemma for our policy formulators, since in order to reduce unemployment, the inflation rate in the economy tends to rise. Thus, of great importance is the need for constructive and well-specified policy recommendations that will help to ameliorate the situation of unemployment and inflation in Nigeria. Below are some policy prescriptions, which will help alleviate the current problems of unemployment and inflation in Nigeria.

i. Government should strive to develop the agricultural sector which has great potentials to increase the supply of farm products and other basic necessities of life. The increased supply will reduce prices and increase in employment generation. To achieve this, various specific agricultural policy measures should be promoted and pursued vigorously.

ii. Massive investments should be carried out in the real sector of the economy, by establishing job-creating industries, which will help to reduce the level of unemployment in the country, increase output, reduce prices of goods and services, and thus, reducing the level of inflation in the economy.

iii. The free flow of information between employers and employees should be enhanced, through the reduction in the cost of job or employee search by means of job data banks, thus resulting to increased efficiency in the labour market. Similarly, training and educational programmes should be increased and geared towards innovations and productivity, thereby, reducing the rate of unemployment in the economy.

iv. It is also recommended strongly that special attention be given to policy implementation. In this regard, the government should set up a policy implementation body or committee in the presidency for the purpose of monitoring government policies and ensuring that they are implemented according to prescriptions.

\section{References}

Adamu, W. (1993). Perspectives Policy and Solutions to Nigeria's Unemployment Problems, Lagos, Economic and Financial Review, CBN.

Adebayo, A (2010).Youth unemployment and the National Directorate of Employment, Selfemployment programmes., The Nigerian Journal of Economic and Social Studies. 
Adebayo, A., \& Ogunrinola, I. O. (2006). Contemporary Dimensions of unemployment problem in Nigeria: A special challenge under the National Economic Empowerment and Development Strategy". NES 2006, Ibadan, Nigeria. Africa: Past Experience and Future Prospects in J. de Melo and A. Panagariya (eds).

Ajibefun, J. S., \& Daramola, S. O. (2003). Labour Management Relations in Nigeria Economic Recovery, Lagos, Management in Feder G., On Exports and Economic Growth Journal.

Alabi, R. A., \& Osasogie I. D. (2006). Income Generation by and 90s: Implication for policy directions in the 21st century. NCEMA Policy Seminal Series. Ibadan, Nigeria. Annual Conference Nigeria and Evans Company.

Aigbokhan, F. (2002). The Socio-economic Situation of Youths in Africa: Problems, Prospects and Options: A Paper Presented at the Youth Employment Summit, Alexandria, Egypt, 1-13.

Balami, G. (2006). Innovation and Growth in Developing Countries, Journal of Development Economics, July. Growth in Developing Countries, Journal of Economic Literature, 33(3), September Growth in the Global Economy (Cambridge, Mass: MIT Press).

Bannock A. (1998). The Theory of Economic Integration between informal and formal sector enterprises in Nigeria”. African Development Review, 13(1).

Bhagwati, R. (1998). Immisering Growth: A Geometrical.

Brahmbhatt, \& Dadush, U. (1996). Disparities in Global.

Briggs, J. E. (1973). Unemployment Statistics and What They mean in Monthly Labour Bulletin, Washington, D.C.U.S. Department of Labour.

Brooman, O. (2006). Manpower Utilization in Nigeria. Analysis of Some causes and consequences of Unemployment, Lagos, FBN Bi-Annual Review.

CBN/FOS/NISER (2001). A study of Nigeria's informal

Central Bank of Nigeria (1987). Annual Report and Statement of Accounts, Lagos, CBN.

Central Bank of Nigeria (1993). Perspectives of Economic Policy Reforms in Nigeria, Lagos, CBN.

Central Bank of Nigeria (1998). Annual Report and Statement of Accounts, Abuja, CBN.

Central Bank of Nigeria (2000). The Changing Structure of the Nigerian Economy and Implications for Development, Lagos, Realm Communications.

Central Bank of Nigeria (2003). Annual Report and Statement of Account,"Abuja, CBN.

Central Bank of Nigeria/World Bank (1994). Employment Policies and Poverty in Nigeria, CBN.

Damachi, G. S. (2001). Socio-Economic Development in Nigeria, Port Harcourt, Pam Unique Publishers.

Dabalen B. C. et al. (2000). Nature and determinants of the linkages

Daramola, S.O. (2003). Inter-Sectoral Indicators of Employment Potential in Nigeria, Monograph Series No. 2, Ibadan, NISER.

Douglason, G. U., \& Gbosi, A. (2006). The Dynamics of Economy 1997, Lagos.

Federal Government of Nigeria. (1997). National Workshop on Employment Statistics, Abuja.

Federal Office of Satistics. (1988). Labour Force Sample Survey,” Lagos, FOS. Foreign Trade (Brighton: Wheatsheaf Press).

Gbosi, A. N. (1993). The Nature, Causes and Consequences of Unemployment on the Nigerian Economy, Pambasad, India, ANVESAK.

Gbosi, A. N. (1997). The Causes and Consequences of Underutilized

Gbosi, A .N. (2004). Under-utilized Human Resources and International Mobility of Labour in Developing Countries. The Nigerian Experience, Cardiff, England, Management Research News. Growth Rate Differences on Kaldorian Lines, Oxford Economic Papers.

Ilo. (1996). World Employment. www.ilo.org In Semi-Industralised Countries, Journal of Development Economics, January.informal economies: The new institutional economic, approach world development.

International Labour Organisation. (1998). World Labour Report, Geneva, ILO Office.

Jorgison, D.V. (1987). Surplus Agricultural Labour and the Development of a Rural Economy, Oxford Economic Papers. 
Keynes, J. M. (1936). The General Theory of Employment, Interest and Money, London, Macmillan.

Mangum, R. (1975). Human Resources and Labour Markets, New York, Harper and Row Publishers. Liberalisation do for Exports and Growth, 30(1).

Meier, G. (1988). International Economics: The Theory of Policy, New York, Oxford Press.

National Bureau of Statistics (2005). The Nigerian statistical Nigeria.Note' Review of Economic Studies, June.

Odusola, A.F. (2001). Nigeria's unemployment problem in the 80s of Customs Unions for Developing Countries, Journal of Political Economy Vol.73. of Development Economics, February/April.

Ojo, F. (1993). Human Resources Management, Lagos, Allen.

Okafor E. E (2011). Youth Unemployment And Implications For Stability Of Democracy In Nigeria. JSDA, 13(1). http://www.jsdafrica.com/Jsda/V13No1

Olalokun, F. O. (1979). Structure of the Nigerian Economy, New York, St. Martins Press. participants in the National Directorate of Employment in Edo State. NES 2006, Ibadan, Nigeria.

Sanda, R. et al. (2006). Nigeria: Youth Unemployment, Poverty - a Time Bomb for Country. Leadership, Wednesday, 27 August

Tairu, F. O. (2003) Urban Unemployment Situation in Nigeria. In E.O. Ezeani and N.N. Elekwa (Eds.). Issues in Urbanization and Urban Administration in Nigeria, 154-167. Enugu: Jamo Enterprises.

World Bank (1998). World Development Indicators," Washington, D.C. The World Bank.

World Bank (2006). World Development Indicators, Washington, D.C., The World Bank.

\section{APPENDIX}

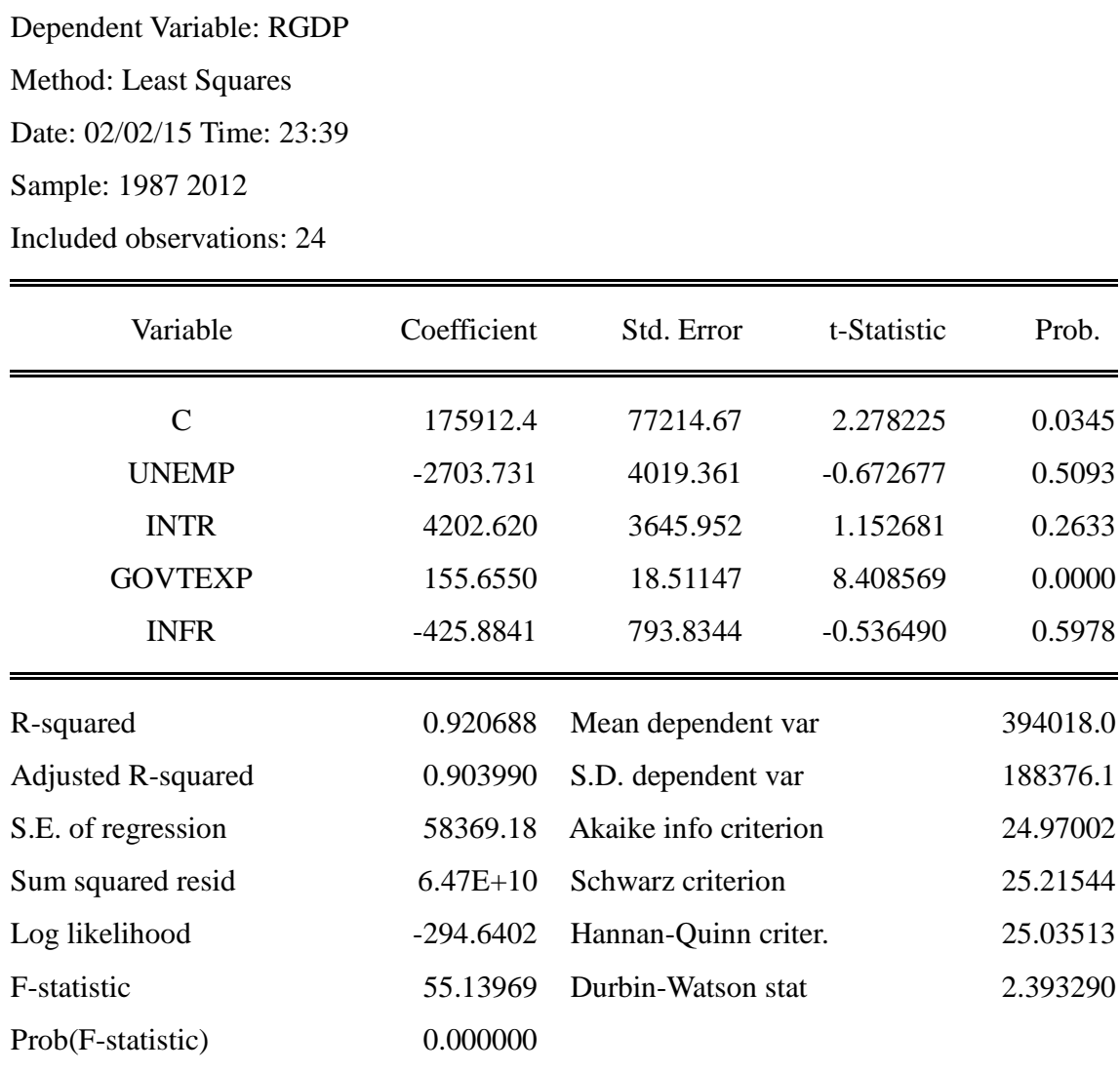

\section{$(\mathrm{cc}) \mathrm{BY}$}

This work is licensed under a Creative Commons Attribution 3.0 License. 